\title{
Relationships between physical and chemical characteris- tics of 3 Sandhills grasses
}

\author{
BRIAN K. NORTHUP AND JAMES T. NICHOLS
}

Authors are research fellow, CSIRO Tropical Crops and Pastures, Davies Laboratory, PMB, PO Aitkenvale, Queensland, Australia 4814 and professor of Agronomy (retired), University of Nebraska. At the time of the research, the authors were graduate research assistant, and professor of agronomy, University of Nebraska, West Central Research and Extension Center, North Platte, Nebr., 69101.

\begin{abstract}
Physical and chemical traits of grass tillers can be strongly correlated. Understanding such patterns would help define physiological development of tillers and changes in quality of forage in Sandhills grasses. Physical and chemical traits were quantified for sand bluestem (Andropogon hallii Hack.), prairie sandreed [Calamovilfa longifolia (Hook.) Scribn.], and little bluestem [Andropogon scoparius (Michx.)] on 3 sites at 4 times (mid-June, July, August, and October) during the 1990 and 1991 growing seasons. Thirty tillers were identified along two, $50-\mathrm{m}$ transects (30 tillers/species/transect) within each site and tiller growth stage, length, and erectness determined. Tiller weight was defined from plants collected within 20 quadrats/site. Protein content, in vitro dry-matter digestibility (IVDMD), hemicellulose, total cell wall, acid detergent fiber (ADF), lignin, ash, total chlorophyll, and nonstructural carbohydrates (TNC) were determined on plant materials representing the dominant growth stages. Relationships among traits of the 3 species were determined by Spearman's rank correlation, and among linear combinations of sets of chemical and physical traits by canonical correlation analysis. Tiller length, weight, and growth stage were positively correlated $(P<0.05)$ and increased with length of growing season. Crude protein, digestibility, hemicellulose and chlorophyll were positively correlated and declined, but negatively correlated with lignin and ash. Significant $(P<0.05)$ correlations between the first canonical variates indicated a strong relationship between tiller maturity/architectural development (physical canonical variate) and forage quality (chemical canonical variate) was present, and large portions of variance in the original variables was defined. Results of this study defined large-scale multi-dimensional relationships between declining forage quality and increasing tiller maturity/architectural development, previously noted in many univariate analyses of limited sets of characteristics.
\end{abstract}

Key Words: canonical correlation, forage quality, structural development, tiller maturation

Tillers of grasses have many distinct physical and chemical characteristics that can define forage quality, plant morphology, and physiological development. Many of the characteristics

\footnotetext{
Published as paper number 12, 204 Journal Series, Nebraska Agriculture Research Division.

Manuscript accepted 21 Jul. 1997
}

involved within these processes are highly related. Tiller morphology impacts plant development, which in turn affects forage quality (Murphy and Briske 1992). Generally, as plants mature, quality variables decline and cell wall fractions increase as plants become taller and structurally complex (Coleman 1992). Forage quality has often been defined by digestibility, protein, cell soluble content, or lack of anti-quality compounds (Van Soest 1982). It is largely dependent on the chemical composition of plant material, which is partially digestible cell wall (mostly cellulose, hemicellulose and lignin) and rapidly digested cell contents (Albersheim 1975, Van Soest 1982). The anti-quality compounds lignin and phenolic acid play important roles in determining forage quality (Akin 1989). Leaf:stem ratios usually decline as plants mature during the growing season, resulting in shifts in forage quality as lignin content in developing stems increases, and protein content and digestibility decline (Coleman 1992, Van Soest 1982).

Many physical and chemical characteristics of important Sandhills grasses have been intensively studied. Analyses of forage quality, cell wall fractions, and physiological activity have been conducted (Hoehne 1966, Burzlaff 1971, Brejda et al. 1989, Hendrickson 1992). However, these studies have been restricted to small subsets of variables and have not considered the relatedness among plant characteristics, or how such relations would impact their results. It must be remembered that forage quality and tiller development are multi-dimensional by nature, and cannot be easily defined with a small set of variables (Coleman 1992, Murphy and Briske 1992). Examining multi-dimensional relationships between composite indices of tiller growth processes, derived from an array of characteristics, would help in understanding the dynamics of physiological development in tillers. The objectives of this study were to: 1 ) define relationships among a set of tiller characteristics for 3 co-dominant warm-season grasses of Sandhills rangeland; and 2) examine relationships between combinations of variables that define large-scale indices of physiological activity and morphological development in tillers of these important forage species.

\section{Materials and Methods}

\section{Site Description}

Experiments were conducted within the overall range research project at the Gudmundsen Sandhills Laboratory near Whitman, 
Nebr. The study area was located along a large stable dune, designated as a composite of range sites including choppy sandhills and rolling sands (Burzlaff 1962). Soils were Valentine fine sands (mixed, mesic Ustipsamments) with high permeability, and low water holding capacity and fertility. All sites were in excellent condition in 1988, with an average condition score of 92 (Table 1). Long-term average annual precipitation was $532 \mathrm{~mm}$. The plant community was classified as tallgrass prairie, and dominated by a mixture of 16 warm-season grasses, in combination with 9 cool-season grasses and grass-likc species, 51 spccies of forbs, and 3 species of shrubs (Northup et al. 1994, Weaver 1965).

Species of interest were the rhizomatous grasses sand bluestem (Andropogon hallii Hack.) and prairie sandreed [Calamovilfa longifolia (Hook.) Scribn.], and the bunchgrass little bluestem [Andropogon scoparius (Michx. Nash]. These 3 species constituted $50-65 \%$ of total forage, and $67 \%$ and $32 \%$ of plant basal area and species composition, respectively (Table 1 ).

Table 1. Average species composition for 3 range sites at the Gudmundsen Sandhills Laboratory, Whitman, Nebr during the 1990-91 growing seasons; values in parntheses are \pm 1 standard error.

\begin{tabular}{|c|c|c|c|}
\hline Forage Species and Classes ${ }^{1}$ & $\begin{array}{l}\text { Basal } \\
\text { Area }^{5}\end{array}$ & $\begin{array}{l}\text { Species } \\
\text { Composition }\end{array}$ & $\begin{array}{l}\text { Standing } \\
\text { Crop }\end{array}$ \\
\hline & \multicolumn{2}{|c|}{$\ldots \ldots-(\%)-\ldots}$. & $-(\mathrm{kg} / \mathrm{ha})-$ \\
\hline Andropogon halli Hack. & 19 & $9(2)$ & $169(12)$ \\
\hline $\begin{array}{l}\text { Calamovilfa longifolia (Hook.) } \\
\text { Scribn. }\end{array}$ & 17 & $10(2)$ & 221 (19) \\
\hline $\begin{array}{l}\text { Andropogon scoparius } \\
\text { (Michx.) Nash }\end{array}$ & 31 & $13(3)$ & $158(14)$ \\
\hline Bouteloua spp. ${ }^{2}$ & 12 & $22(4)$ & $31(7)$ \\
\hline Other Warm-season grasses & 14 & $11(4)$ & $168(20)$ \\
\hline $\begin{array}{l}\text { Cool-season grasses and Grass- } \\
\text { like species }\end{array}$ & 2 & $26(8)$ & $88(13)$ \\
\hline Forbs & 5 & $9(5)$ & $135(25)$ \\
\hline
\end{tabular}

Nomenclature follows The Great Plains Flora Association (1986).

${ }_{3}$ Boutelous gracilis (H.B.K.) Lag Ex. Griffiths, and Boutelowa hirsuta Lag.

${ }^{3}$ Other warm-season grasses included Dicanthelium oligosanthes (Schult.) Gould var. scribnerianum (Nash) Gould, Dichanthelium wilcoxianum (Vasey) Freckman, Paspalum setaceum Michx. Var. stramineum (Nash) D. Banks, Muhlenbergia pungens Thurb., and Sporobolos cryptandrus (Torr.) A. Gray.

Cool-season grasses included Agropyron smithii Kydb., Koelaria pyrimidata (Lam.) Beav., Stipa comata Trin. and Rupr., and Stipa spartea Trin. Grass-like species were Carex eleocharis Bailey and Cypenus schweinitzii Torr.

Pre-study mean basal area conducted in 1988. Mean total basal cover for all perennial plants was $18 \%$

\section{Experimental Design}

Data were collected from 3 different sites, based on topography and relief, during the 1990 and 1991 growing seasons to encompass variation in plant characteristics. Sites were; 1) choppy sandhills, 2) rolling sands, and 3) transitional zones between choppy sandhills and rolling sands. Data related to physical and chemical characteristics of tillers were collected within short time periods during mid-June, July, August, and October each year of the study.

\section{Data Collection}

I. Physical Characteristics. Thirty tillers of each species were randomly located along each of two, 50-m transects per site ( $\mathrm{n}=$ 60 tillers/species/site). Length of tillers were measured to the nearest $1 \mathrm{~mm}$. Degree of erectness of tillers were assigned to a 4point scale of 1 (fully erect) to 4 (fully prostrate), based on the angle of materials within a 90 degree arc $\left(1=90-61^{\circ}, 2=\right.$ $\left.60^{\circ}-41^{\circ}, 3=40-21^{\circ}, 4=20-0^{\circ}\right)$. Growth stage was defined by the Nebraska system of growth staging, with stage of maturity determined by existing vegetative leaves, transitional nodes, or reproductive structures, and reported as mean stage by count (Moore et al. 1991). Mean weight per tiller was determined by collection of plant materials and tiller counts within twenty, 0.25 $\mathrm{m}^{2}$ quadrats randomly located along $25 \mathrm{~m}$ transects within sites.

\section{Chemical Characteristics.}

Plant materials of each species were collected by the predominant stages of growth present at time of data collection from twenty, $0.25 \mathrm{~m}^{2}$ quadrats randomly located along two, $25 \mathrm{~m}$ transects per site. Collected herbage was dricd at $60^{\circ} \mathrm{C}$ for 48 hours, ground to pass a $1 \mathrm{~mm}$ sieve, and composited by species.

In vitro dry-matter digestibility (IVDMD) was determined by 48 hour fermentation, followed by 24 -hour incubation with 0.5 $\mathrm{ml}$ of pepsin solution $(0.2 \mathrm{~g}$ pepsin $/ 1 \mathrm{ml}$ water) and concentrated HCL (Marten and Barnes 1979). Percent crude protein $(\mathrm{N} \times$ 6.25) was calculated from the amount of nitrogen in samples as determined by micro-Kjeldahl techniques (Bremner 1965). Cell wall fractions were described by detergent fiber analysis (Goering and Van Soest 1970). Neutral detergent fiber (NDF) was assayed to define the amount of total cell wall present in forages. Acid detergent fiber (ADF) was determined, and residues were used in analyses for acid detergent lignin content (Goering and Van Soest 1970). Hemicellulose was calculated as the difference between NDF and ADF. Samples were analyzed in duplicate for all characteristics.

Chlorophyll content and total nonstructural carbohydrates (TNC) were determined on plant tissues collected from randomly located $0.25 \mathrm{~m}^{2}$ quadrats within experimental areas. Materials were collected from quadrats until 8 sub-samples/species (1 subsample/quadrat) were obtained per site, and stored on ice during collection and transport. Collected materials were composited by species and frozen until analyzed. At the time of analyses, materials were divided into 2 portions. One portion was dried at $60^{\circ} \mathrm{C}$ to a consistent weight, ground to pass a $1 \mathrm{~mm}$ screen, and analyzed for TNC in duplicate by extraction in $0.2 \mathrm{~N} \mathrm{H}^{2} \mathrm{SO}_{4}$, and determination on a glucose equivalent basis by iodometric titration (AOAC 1965, Smith et al. 1964). Leaf materials of the second portion were chopped into $3 \mathrm{~mm}$ sized pieces and chlorophyll extracted (in triplicate) in dimethyl sulfoxide in a $65^{\circ} \mathrm{C}$ water bath. Extracts were separated, diluted serially, and analyzed by spectrophotometer (Hiscox and Israelstam 1979). Absorbance readings were applied to modified simultaneous equations of Arnon (1949) and chlorophyll content determined (Porra et al. 1989).

\section{Statistical Analysis}

Log $(Y+1)$ transformations were applied to all variables, and transformed values were standardized by unit variance (Ludwig and Reynolds 1988). Relationships among the different forage characteristics of the 3 species were examined by Spearman's rank-order correlations applied to log transformations (SAS 1986). Relationships between groups of variables defining physical and chemical characteristics of tillers were analyzed by canonical correlations applied to standardized values (NCSS 1990, SAS 1986). Canonical correlation analysis is the multivariate extension of correlation analysis, and can be used to simultaneously analyze mixtures of variables defining different processes (Bidwell and Engle 1992). This procedure uses linear canonical equations with multiple dependent and independent variables comprised of weighted averages. Canonical correlations 
find a linear combination from each set of variables such that correlations between each set is maximized, then defines additional sets of canonical variables, uncorrelated with the first pair, that produce the next highest correlation coefficient(s). The process continues until the number of canonical correlations equals the number of variables in the smallest group (Johnson and Wichern 1988). Only the results of the first canonical correlations were presented, since additional canonical correlations added little to interpretations. Correlations between canonical and original variables, and plots of the first canonical correlations between the first pair of canonical variates were included to aid in interpretion. Level of significance was set at $\alpha=0.05$ for all statistical tests.

\section{Results and Discussion}

Physical and Chemical Characteristics. Growth stage of all 3 species increased with length of growing season, as did tiller length and weight (Table 2). The largest increases were noted late in the growing season, when plants were undergoing most of the stem elongation and development of reproductive structures. Sand bluestem and little bluestem tillers both grew at steady rates during the growing season, as compared to prairie sandreed plants which developed rapidly during the early growing season and levelled off as the dormant season approached (Table 2). Increases in growth stage of sand bluestem and prairie sandreed during the growing season were similar to results of another study conducted on similar sites, during the same years (Hendrickson 1992). Prairic sandreed and little bluestem tillers tended to be more erect than sand bluestem later in the growing season.

Growing season impacted most of the physical attributes through its effects on plant maturation processes common to all 3 species (Dahl and Hyder 1977). Tiller initiation and growth are qualitatively similar within the members of Poaceae, being controlled and localized in meristematic tissues (Murphy and Briske 1992). Increases in tiller erectness were related to the elevation of the meristematic tissues in the growing points, and the development of stems (Brejda et al. 1989).

Environmental variables an impact on tiller development. Radiation, temperature, photoperiod, water availability, and mineral nutrition all impact tillering, either singly or in combination (Murphy and Briske 1992). The effects of precipitation on tiller development in this study were important. Precipitation received in 1991 generally exceeded the long-term average, while 1990 approximated the long-term average (Table 3). Most of the annual precipitation was received during the growing season (April-September), with lesser amounts received during the remainder of the year. Timing and amount of rainfall would impact level of growth tillers attained during the growing seasons. Soil moisture was adequate for the initiation of growth in the spring, and amounts received during the different parts of the growing season (April-June and July-September) would have allowed plants to attain average levels of development. Maximum tiller growth and development also occurred during maximum inputs (July and August) of solar radiation (Tieszen 1970).

Crude protein, IVDMD, hemicellulose, and chlorophyll all declined with the advance of growing season, while lignin and ash increased (Table 2). Total cell wall and TNC did not display marked changes over the course of the growing season. Results of laboratory analyses were similar to those of earlier studies at other Sandhills sites (Burzlaff 1971, Hoehne 1966). Total cell wall (NDF) was generally higher than values reported in earlier studies, though within the realm of values possible in previous studies; the increase was likely related to climate and precipitation. Changes in chlorophyll content during the growing season have not been reported for these 3 species. Only point data during the growing season exists, generally the peak period of photosynthetic activity (Tieszen 1970). Differences in chemical characteristics during grazing treatments were due to the same factors that affected physical characteristics- advancing plant maturity and environmental factors.

Correlation Analysis. Growth stage of sand bluestem was positively correlated $(P<0.05)$ to tiller length, weight, lignin, ADF,

Table 2. Mean ( \pm 1 standard error) physical traits of tillers and chemical characteristics of 3 warm-season grasses of the Nebraska Sandhills during the 1990-91 growing seasons.

\begin{tabular}{|c|c|c|c|c|c|c|c|c|c|c|c|c|}
\hline & \multicolumn{4}{|c|}{ Sand Bluestem } & \multicolumn{4}{|c|}{ Prairie Sandreed } & \multicolumn{4}{|c|}{ Little Bluestem } \\
\hline & Jun. & Jul. & Aug. & Oct. & Jun. & Jul. & Aug. & Oct. & Jun. & Jul. & Aug. & Oct. \\
\hline \multicolumn{13}{|l|}{ Physical Traits } \\
\hline Erectness' & $1.7(0.2)$ & $1.8(0.1)$ & $1.8(0.1)$ & $1.6(0.2)$ & $1.3(0.1)$ & $1.3(0.1)$ & $1.2(0.1)$ & $1.2(0.1)$ & $1.8(0.2)$ & $1.7(0.1)$ & $1.5(0.2)$ & $1.3(0.1)$ \\
\hline Growth Stage ${ }^{2}$ & $1.3(0.1)$ & $1.4(0.1)$ & $1.8(0.1)$ & $2.1(0.3)$ & $1.3(0.1)$ & $1.6(0.1)$ & $2.1(0.3)$ & $2.8(0.4)$ & $1.4(0.1)$ & $1.9(0.3)$ & $2.5(0.2)$ & $3.2(0.3)$ \\
\hline Tiller Length, cm & $28(3)$ & $31(3)$ & $35(4)$ & $38(5)$ & $40(4)$ & $48(4)$ & $50(5)$ & $58(4)$ & $18(1)$ & $20(1)$ & $23(3)$ & $26(2)$ \\
\hline Tiller Weight, g & $0.2(0.04)$ & $0.4(0.1)$ & $0.4(0.1)$ & $0.6(0.2)$ & $0.4(0.1)$ & $0.5(0.1)$ & $0.6(0.1)$ & $0.7(0.1)$ & $0.1(0.01)$ & $0.2(0.02)$ & $0.2(0.05)$ & $0.3(0.04)$ \\
\hline \multicolumn{13}{|l|}{ Chemical Traits } \\
\hline Protein, \% & $9.0(0.3)$ & $7.6(0.6)$ & $6.9(0.8)$ & $5.4(0.4)$ & $9.6(0.4)$ & $7.3(0.7)$ & $6.9(0.6)$ & $3.9(0.7)$ & $9.8(0.4)$ & $8.1(0.8)$ & $6.9(0.9)$ & $3.6(0.6)$ \\
\hline IVDMD,$\%^{3}$ & $69(2)$ & $64(2)$ & $58(1)$ & $50(2)$ & $52(4)$ & $44(3)$ & $39(2)$ & $37(2)$ & $62(2)$ & $53(3)$ & $46(4)$ & $32(3)$ \\
\hline Cell Wall, $\%^{4}$ & $64(1)$ & $64(1)$ & $64(1)$ & $66(1)$ & $71(1)$ & $71(1)$ & $70(1)$ & $70(1)$ & $68(2)$ & $68(1)$ & $69(1)$ & $68(1)$ \\
\hline Hemicellulose, \% & $24(2)$ & $25(1)$ & $24(1)$ & $21(1)$ & $28(1)$ & $27(1)$ & $26(1)$ & $23(1)$ & $30(1)$ & $29(2)$ & $28(1)$ & $23(1)$ \\
\hline $\mathrm{ADF}, \%^{5}$ & $40(2)$ & $40(2)$ & $40(1)$ & $45(1)$ & $43(1)$ & $44(1)$ & $44(1)$ & $47(1)$ & $38(1)$ & $39(1)$ & $41(0.6)$ & $45(0.4)$ \\
\hline Ash, \% & $3.4(0.3)$ & $3.4(0.4)$ & $3.1(0.3)$ & $3.9(0.5)$ & $2.4(0.5)$ & $2.8(0.3)$ & $3.6(0.4)$ & $3.7(0.6)$ & $3.1(0.3)$ & $3.4(0.3)$ & $4.4(0.2)$ & $6.1(0.2)$ \\
\hline Lignin, \% & $3.7(0.4)$ & $3.9(0.4)$ & $4.2(0.2)$ & $5.1(0.3)$ & $4.1(0.1)$ & $4.3(0.2)$ & $4.6(0.2)$ & $5.8(0.2)$ & $4.3(0.1)$ & $4.2(0.3)$ & $4.6(0.3)$ & $5.7(0.1)$ \\
\hline $\mathrm{TNC}, \mathrm{mg} / \mathrm{g}^{6}$ & $85(7)$ & $94(9)$ & $94(8)$ & $89(6)$ & $82(5)$ & $87(4)$ & $93(12)$ & $859(6)$ & $94(4)$ & $96(5)$ & $95(4)$ & $94(19)$ \\
\hline Chlorophyll, mg/g & $1.7(0.4)$ & $1.5(0.3)$ & $1.4(0.3)$ & $0.6(0.3)$ & $1.8(0.3)$ & $1.4(0.2)$ & $1.4(0.1)$ & $0.7(0.2)$ & $1.8(0.3)$ & $1.7(0.2)$ & $1.6(0.2)$ & $1.1(0.4)$ \\
\hline
\end{tabular}

Erectness scores ranged from 1 (fully erect) to 4 (fully prostrate).

${ }_{3}^{2}$ Growth stage as determined by mean stage by count (Moore et al. 1991).

${ }^{3}$ Total cell wall as defined by neutral detergent fiber.

4 In vitro dry-matter digestibility.

${ }_{6}^{5}$ Acid detergent fiber.

6otal nonstructural carbohydrates. 
Table 3. Precipitation during $1990-91$ and the 30 year average (1961-90) at the Gudmundsen Sandhills Laboratory, Whitman, Nebr.

\begin{tabular}{lrcc}
\hline \hline Month & 1990 & 1991 & Average $^{T^{-}}$ \\
\hline & & $(\mathrm{mm})$ & \\
January-March & 74 & 111 & 70 \\
April-June & 171 & 261 & 234 \\
July-September & 198 & 209 & 186 \\
October-December & 67 & 93 & 70 \\
\hline
\end{tabular}

${ }^{\top}$ Precipitation data is from the Mullen $21 \mathrm{NW}$ reporting site, located $10 \mathrm{~km}$ northeast of the study site (NOAA 1991).

and cell wall, and negatively to crude protein, IVDMD, hemicellulose, and chlorophyll (Table 4). Correlations between tiller length and weight, and the remaining chemical variables were correlated in a similar fashion. Tiller erectness and TNC were not correlated to any other characteristic. Ash content was positively correlated $(\mathrm{P}<0.05)$ to all cell wall fractions except hemicellulose. Crude protein, IVDMD, and chlorophyll were positively correlated, and negatively correlated to all cell wall fractions except hemicellulose. Total cell wall, ADF, and lignin were positively correlated (Table 4 ).

Similar correlations between chemical and physical variables were noted in prairie sandreed and little bluestem (Tables 5, 6). Erectness of prairie sandreed was negatively correlated to growth stage and lignin, while TNC and tiller length were positively correlated (Table 5). Ash content in prairie sandreed was negatively correlated with protein, IVDMD, hemicellulose, and chlorophyll, but positively correlated to growth stage, tiller weight, and lignin. Tiller erectness and the remaining physical characteristics of little bluestem were negatively correlated, while crude protein, IVDMD, hemicellulose, and chlorophyll were positively correlated (Table 6). Ash content in little bluestem was negatively correlated to crude protein, IVDMD, hemicellulose, and chlorophyll. Growth stage, tiller length, tiller weight, and lignin were positively correlated.

The significance and signs of the correlations between physical characteristics, and those chemical characteristics defining cell wall fractions and forage palatability, indicated that definable large-scale relationships existed. Similar results have been noted in a correlation analysis applied to quality traits in smooth bromegrass (Bromus inermis L.) paddocks (Jung et al. 1989). These relationships were apparently related to common elements of plant morphology and physiology in grasses (Dahl and Hyder 1977).

Canonical Correlations. Robust relationships were noted between physical characteristics of tillers and chemical traits of forages for all 3 species. Acid detergent fiber (ADF) was excluded due to linear dependencies with hemicellulose and lignin, since both were determined from ADF residues (Johnson and Wichern 1988). Canonical coefficients for physical characteristics were of similar size across species, as were signs of coefficients, except tiller weight and erectness of sand bluestem and tiller length of little bluestem (Table 7). The canonical coefficients for chemical characteristics exhibited less similarity in relative size and signs of coefficients across species (Table 7). The size of coefficients for IVDMD, hemicellulose, and chlorophyll were different, while total cell wall was similar. Signs of coefficients for crude protein, hemicellulose, lignin, TNC and chlorophyll were variable across species.

Some of the variation noted in size and sign of canonical coefficients for physical and chemical characteristics can be related to fundamental differences in plant physiology, growth form, and tiller morphology. Similarities in coefficients were indicative of common processes involved in tiller morphology and growth. Phytomers, the basic structural unit of a tiller, develop sequentially from an apical meristem, with axillary buds (rudimentary apical meristems) differentiated as components of each phytomer (Murphy and Briske 1992). Differences in coefficients were probably related to growth form. Little bluestem is a bunchgrass, as compared to the other 2 clonal species, and had higher levels of chlorophyll in its leaves, possibly a compensatory mechanism due to intra-tiller shading within bunches. Growth stages attained by little bluestem were more advanced during the later treatments, due to some level of synchronization of tiller development within bunches (Northup 1993). Tillers of prairie sandreed exhibited elements of both a cool- and warm-season grass. Initial tiller growth occurred earlier in the growing season than the bluestems,

Table 4. Spearman's correlation among forage characteristics of sand bluestem at different times during the 1990-90 growing seasons on the Gudmundsen Sandhills Laboratory $(\mathrm{n}=24 \mathrm{~d} . \mathrm{f}$ ) ; * significantly different, $\mathrm{p}<0.05$.

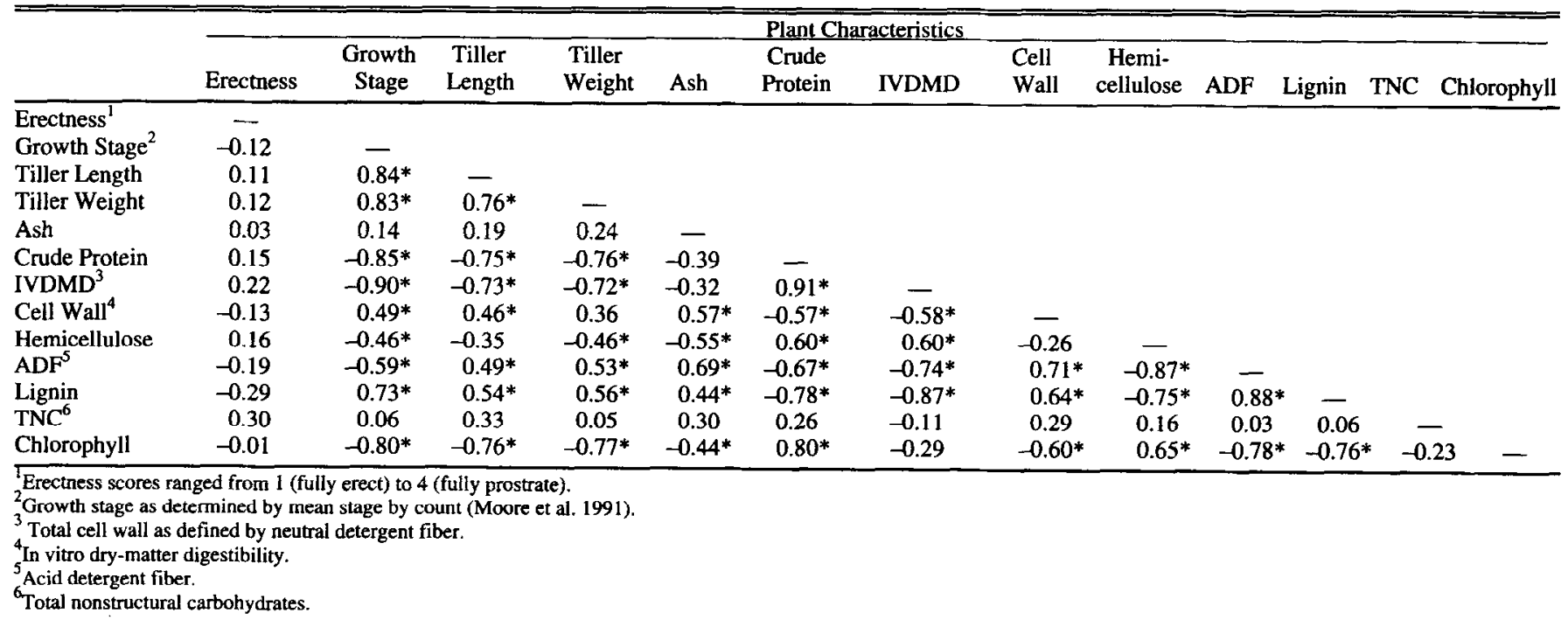


Table 5. Spearman's correlation coefficients among forage characteristics of prairie sandreed at different times during the 1990-90 growing seasons on the Gudmundsen Sandhills Laboratory ( $n=24$ d.f.); significantly different, $p<0.05$.

\begin{tabular}{|c|c|c|c|c|c|c|c|c|c|c|c|c|c|}
\hline & \multicolumn{13}{|c|}{ Plant Characteristics } \\
\hline & Erectness & $\begin{array}{c}\text { Growth } \\
\text { Stage }\end{array}$ & $\begin{array}{l}\text { Tiller } \\
\text { Length }\end{array}$ & $\begin{array}{c}\text { Tiller } \\
\text { Weight }\end{array}$ & Ash & $\begin{array}{l}\text { Crude } \\
\text { Protein }\end{array}$ & IVDMD & $\begin{array}{l}\text { Cell } \\
\text { Wall }\end{array}$ & $\begin{array}{l}\text { Hemi- } \\
\text { cellulose }\end{array}$ & ADF & Lignin & TNC C & Chlorophyll \\
\hline Erectness ${ }^{1}$ & - & & & & & & & & & & & & \\
\hline T'iller Length & -0.32 & $0.75^{*}$ & - & & & & & & & & & & \\
\hline Tiller Weight & -0.18 & $0.73 *$ & $0.60^{*}$ & - & & & & & & & & & \\
\hline Ash & -0.25 & $0.63^{*}$ & 0.32 & $0.56^{*}$ & - & & & & & & & & \\
\hline Crude Protein & 0.39 & $-0.92 *$ & $-0.73^{*}$ & $-0.76^{*}$ & $-0.61 *$ & - & & & & & & & \\
\hline Hemicellulose & 0.35 & $-0.80^{*}$ & -0.40 & $-0.74 *$ & $-0.64 *$ & $0.85^{*}$ & $0.66^{*}$ & $0.44^{*}$ & - & & & & \\
\hline $\mathrm{ADF}^{5}$ & -0.34 & $-0.71^{*}$ & 0.35 & $0.79^{*}$ & $0.57^{*}$ & $-0.79^{*}$ & $-0.64^{*}$ & 0.03 & $-0.88 *$ & - & & & \\
\hline Lignin & $-0.47^{*}$ & $0.83 *$ & $0.45^{*}$ & $0.73^{*}$ & $0.61 *$ & $-0.84 *$ & $-0.69 *$ & $-0.14 *$ & $-0.89 *$ & $0.92 *$ & - & & \\
\hline $\mathrm{TNC}^{6}$ & -0.07 & 0.22 & $0.46 *$ & 0.23 & 0.09 & -0.17 & -0.35 & -0.04 & 0.04 & -0.07 & -0.04 & - & \\
\hline Chlorophyll & -0.40 & $-0.88^{*}$ & $-0.65^{*}$ & $-0.76^{*}$ & $-0.53^{*}$ & $0.90^{*}$ & 0.75 & 0.11 & $0.72 *$ & $-0.74 *$ & $-0.82^{*}$ & -0.03 & - \\
\hline
\end{tabular}

Erectness scores ranged from 1 (fully erect) to 4 (fully prostrate).

${ }_{3}^{2}$ Growth stage as determined by mean stage by count (Moore et al. 1991).

${ }^{3}$ Total cell wall as defined by neutral detergent fiber.

${ }^{4}$ In vitro dry-matter digestibility.

5 Acid detergent fiber.

${ }^{6}$ Total nonstructural carbohydrates.

and plants continued to be photosynthetically active well into the dormant season. Prairie sandreed tillers initiated growth in lateApril and May, and elevated growing points beginning in lateMay (Brejda et al. 1989). Conversely, sand bluestem emerged in early-June and had fewer elongated tillers during the growing season (Hendrickson 1992). Tillers of the 2 bluestems had largely senesced by October, though the basal portions of some little bluestem plants within tussocks were still photosynthetically active. Some prairie sandreed tillers can be biennial, emerging in the late growing season of 1 year, over-wintering, and resuming growth from the same shoot apex the next year (Brejda et al. 1989). Some of the variation in coefficients for chemical characteristics was likely related to differences in cell wall structure and biochemical activity, resulting in different levels of cell wall constituents (Albersheim 1975). Prairie sandreed produces wiry and tough forage, with higher levels of cell wall and lower digestibili- ty regardless of time of year, resulting in a lower value for forage quality (Burzlaff 1971).

The first canonical correlation indicated that the first 2 sets of canonical variates were highly correlated. Significant relationships were noted between composite indices of physical characteristics of tillers and chemical traits of forage, as described by the canonical correlation and Wilk's lambda (Table 7). Large amounts of variance present in the original sets of physical and chemical characteristics were defined by the first pair of canonical variates. The physical canonical variate described $>50 \%$ of the total variance for all 3 species, and was particularly efficient for little bluestem (Table 7). The chemical canonical variate also defined $>50 \%$ of the total variance present in the original set of variables for prairie sandreed and little bluestem, and $44 \%$ of the variance in sand bluestem. The remaining pairs of canonical variates added little to the analysis of all 3 species. Lower levels of

Table 6. Spearman's correlation coefficients among forage characteristics of little bluestem at different times during the $1990-90$ growing seasons on the Gudmundsen Sandhills Laboratory $(n=24$ d.f.); significantly different, $p<0.05$.

\begin{tabular}{|c|c|c|c|c|c|c|c|c|c|c|c|c|c|}
\hline & \multicolumn{13}{|c|}{ Plant Characteristics } \\
\hline & Erectness & $\begin{array}{c}\text { Growth } \\
\text { Stage }\end{array}$ & $\begin{array}{l}\text { Tiller } \\
\text { Length }\end{array}$ & $\begin{array}{l}\text { Tiller } \\
\text { Weight }\end{array}$ & Ash & $\begin{array}{l}\text { Crude } \\
\text { Protein }\end{array}$ & IVDMD & $\begin{array}{l}\text { Cell } \\
\text { Wall }\end{array}$ & $\begin{array}{l}\text { Hemi- } \\
\text { cellulose }\end{array}$ & $\mathrm{ADF}$ & Lignin & TNC & Chlorophyll \\
\hline $\begin{array}{l}\text { Erectness }{ }^{1} \\
\text { Growth Stage } 2\end{array}$ & $-\overline{0.82 *}$ & - & & & & & & & & & & & \\
\hline Tiller Length & $-0.85^{*}$ & $\overline{0.92 *}$ & - & & & & & & & & & & \\
\hline Tiller Weight & $-0.78^{*}$ & $0.91 *$ & $0.88^{*}$ & - & & & & & & & & & \\
\hline Ash & -0.37 & $0.62^{*}$ & $0.42 *$ & $0.49 *$ & - & & & & & & & & \\
\hline Crude Protein & $0.76^{*}$ & $-0.95 *$ & $-0.87 *$ & $-0.85 *$ & $-0.61^{*}$ & - & & & & & & & \\
\hline IVDMD $^{3}$ & $0.78 *$ & $-0.98 *$ & $-0.91 *$ & $-0.91 *$ & $-0.63 *$ & $0.98^{*}$ & - & & & & & & \\
\hline Cell Wall ${ }^{4}$ & -0.11 & 0.12 & -0.16 & 0.08 & -0.12 & -0.16 & -0.18 & - & & & & & \\
\hline Hemicellulose & 0.74 & $-0.86^{*}$ & -0.74 & $-0.72 *$ & $-0.75^{*}$ & $0.89 *$ & $0.87^{*}$ & 0.13 & - & & & & \\
\hline $\mathrm{ADF}^{5}$ & $-0.67 *$ & $0.88^{*}$ & $0.77 *$ & $0.72 *$ & $0.67 *$ & $-0.92^{*}$ & $-0.91 *$ & 0.30 & $-0.91 *$ & - & & & \\
\hline Lignin & $-0.67 *$ & $0.91 *$ & $0.83^{*}$ & $0.80^{*}$ & $0.57^{*}$ & $-0.93 *$ & $-0.94 *$ & -0.34 & $-0.85^{*}$ & $0.95 *$ & - & & \\
\hline TNC ${ }^{6}$ & -0.03 & -0.11 & -0.06 & -0.11 & -0.39 & -0.02 & 0.07 & 0.18 & 0.08 & -0.01 & -0.02 & - & \\
\hline Chlorophyll & $-0.67 *$ & $0.67^{*}$ & $-0.77^{*}$ & $-0.73^{*}$ & $-0.65^{*}$ & $0.76^{*}$ & $-0.79 *$ & 0.10 & $0.80 *$ & $-0.73^{*}$ & $-0.72^{*}$ & -0.31 & - \\
\hline
\end{tabular}

${ }_{2}$ Erectness scores ranged from I (fully erect) to 4 (fully prostrate).

${ }_{3}^{2}$ Growth stage as determined by mean stage by count (Moore et al. 1991).

${ }^{3}$ Total cell wall as defined by neutral detergent fiber.

${ }_{5}^{4}$ In vitro dry-matter digestibility.

5 Acid detergent fiber.

60tal nonstructural carbohydrates. 
Table 7. Canonical coefficients for the first canonical correlation between physical and chemical characteristies of tillers of 3 warm-season grasses, and statistical analyses. ${ }^{1}$

\begin{tabular}{|c|c|c|c|}
\hline Variable & Sand Bluestem & Prairie Sandreed & Little Bluestem \\
\hline \multicolumn{4}{|c|}{ Canonical Coefficients } \\
\hline \multicolumn{4}{|l|}{ Physical Variables } \\
\hline Erectness & -0.06 & 0.08 & 0.16 \\
\hline Growth Stage $^{2}$ & 0.99 & 0.91 & 0.81 \\
\hline Tiller Length & -0.07 & -0.11 & 0.12 \\
\hline Tiller Weight & 0.06 & 0.26 & 0.23 \\
\hline \multicolumn{4}{|l|}{ Chemical Variables } \\
\hline Crude Protein & 0.09 & -0.08 & -0.09 \\
\hline IVDMD $^{3}$ & 0.81 & 0.16 & 1.10 \\
\hline Cell Wall & 0.13 & 0.11 & 0.16 \\
\hline Hemicellulose & -0.32 & 0.19 & -0.39 \\
\hline Lignin & 0.03 & -0.21 & -0.28 \\
\hline Ash & 0.03 & -0.07 & -0.03 \\
\hline $\mathrm{TNC}^{4}$ & 0.21 & -0.16 & 0.02 \\
\hline \multirow[t]{2}{*}{ Chlorophyll } & 0.48 & 0.53 & -0.08 \\
\hline & \multicolumn{3}{|c|}{ Statistical Analysis } \\
\hline Canonical Correlation & 0.95 & 0.96 & 0.98 \\
\hline $\begin{array}{l}\mathrm{p}>\mathrm{F} \\
\text { Wilk's Lambda }^{6} \\
\text { Variance Defined }^{7}\end{array}$ & $\begin{array}{r}<0.01 \\
0.03\end{array}$ & $\begin{array}{l}<0.01 \\
<0.01\end{array}$ & $\begin{array}{r}<0.01 \\
0.01\end{array}$ \\
\hline $\begin{array}{l}\text { Physical } \\
\text { Chemical }\end{array}$ & $\begin{array}{l}54 \\
44\end{array}$ & $\begin{array}{l}56 \\
58\end{array}$ & $\begin{array}{l}82 \\
56\end{array}$ \\
\hline \multicolumn{4}{|c|}{$\begin{array}{l}\text { Numerator d.f. }=32 \text {, denominator d.f. }=45.8 \text { for tests on canonical correlations; d.f. are } \\
\text { approximations. } \\
2 \text { Growth stage by Mean Stage by Count. } \\
\text { 3 In vitro dry-matter digestibility. } \\
\text { 4'Total nonstructural carbohydrates. } \\
\text { 5 Correlation between first canonical variates of chemical and physical charactertistics. } \\
\text { 'Significance of correlation increases as Wilk's lambda approaches zem. } \\
\text { 'Percent of variance present in original variables defined by new canonical variates. }\end{array}$} \\
\hline
\end{tabular}

variance defined in the physical characteristics for sand bluestem and prairie sandreed, and chemical characteristics of sand bluestem, were apparently related to their clonal growth form. Both species produced large numbers of growth stages late in the growing season, resulting in a population of tillers with a wide range of both quality and physical size and age. The populations of tillers of sand bluestem and prairie sandreed contained 23 dif- ferent stages of phenological development by the August collections (Hendrickson 1992, Northup 1993).

Correlations between the first pair of canonical variates and the original set of variables indicated that definable relationships between groups of related characteristics could be developed. Canonical variates were interpreted as composite indices of maturity and architectural development of tillers (physical canonical variate), and quality of plant materials (chemical variate) comprising tillers (Table 8). The chemical variate was a combination of relationships involving both positive and negative effects on quality. It was positively correlated with the high palatability factors crude protein, IVDMD, chlorophyll, and hemicellulose, and negatively correlated with lignin, an indicator of anti-quality. As such, the important driving factors in the chemical variate was an increase in anti-quality coupled with a corresponding decrease in palatability with advance of the growing season. The impacts of lignin as an anti-quality factor in forages has been well documented (Akin 1989). The relationship between the chemical variables and the forage quality variate emphasizes the multi-dimensional nature and relatedness between both palatability and antiquality characteristics that are involved in describing forage quality (Coleman 1992). The "tiller maturity" variate exhibited positive correlations with growth stage, tiller length, and weight (Table 8). Tillers tended to be larger and more phenologically advanced later in the growing season, when mean tiller maturity was greater and plants were structurally more complex. Some cohorts of tillers in the late growing season were comprised of old and new leaves, elongated and elongating stems, and reproductive structures (Hendrickson 1992).

Plots for all 3 species indicated the existence of close relationships between tiller development and forage quality (Fig. 1). Distributions of observations accentuated relationships among characteristics comprising the canonical variates, and between canonical variates. Observations in the lower part of both axes $(<0)$ were predominately vegetative or early elongation stages of development, with corresponding high digestibilities and crude protein. Observations later in the growing season were located in the upper parts of both axes and corresponded to

Table 8. Correlations between original physical and chemical variables of 3 warm-season grasses and the canonical variates of the first canonical correlation.

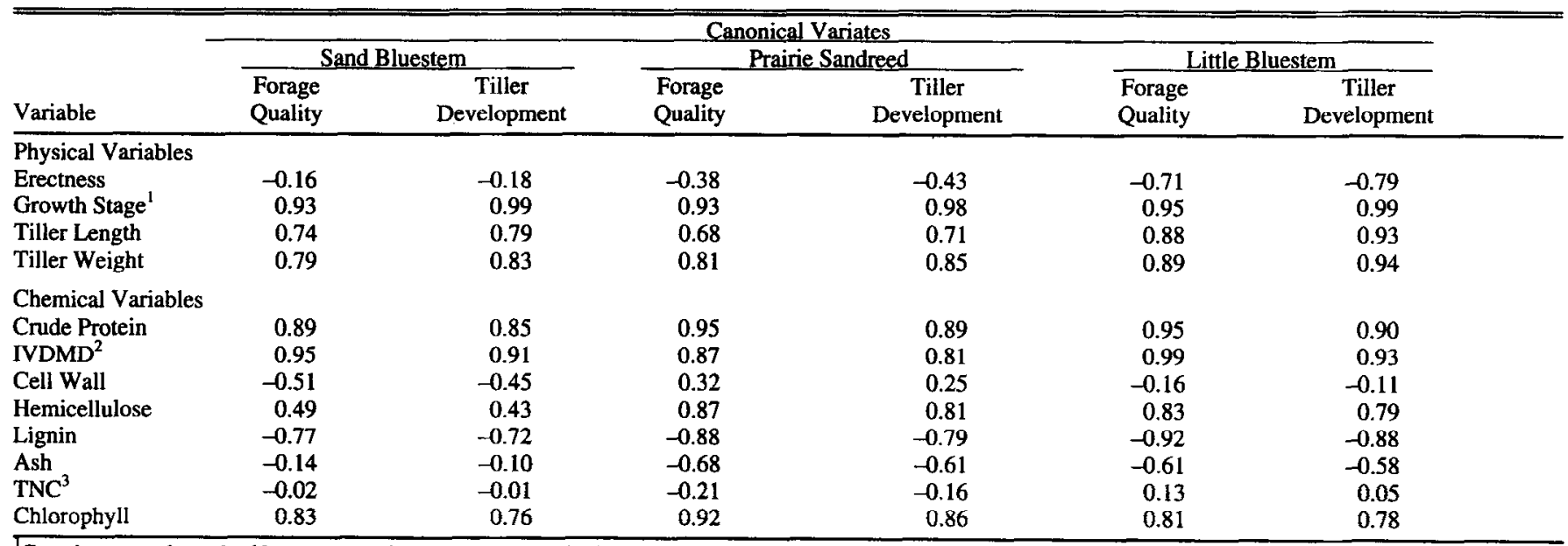

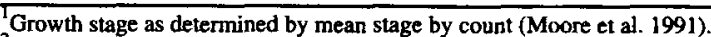

2 In vitro dry-matter digestibility.

${ }^{3}$ Total nonstructural carbohydrates. 
older, structurally complex tillers with high lignin contents and low digestibility and crude protein.

Data generated during this study encompassed levels of variation present in both advance of the growing season, and the effects of precipitation on tiller maturity (Fig. 1). Tillers of all 3

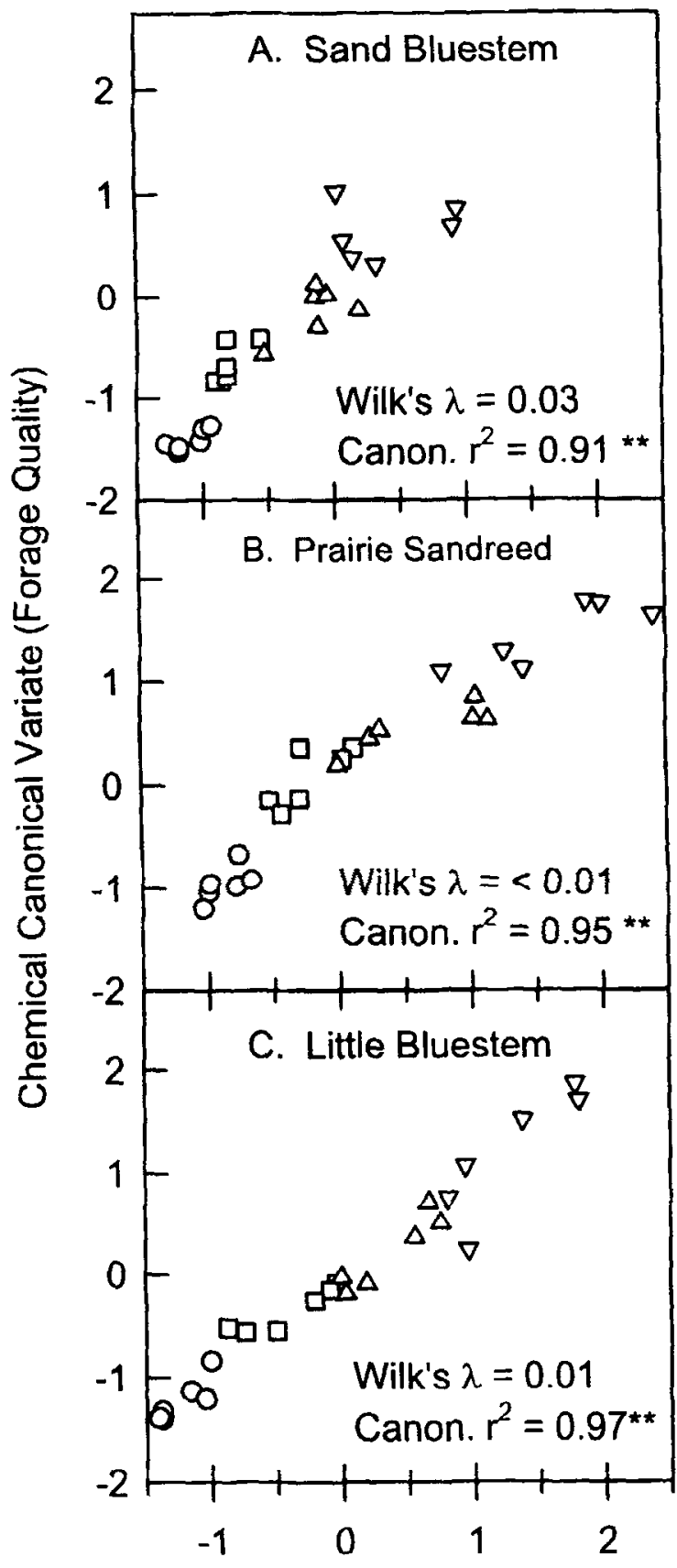

Physical Canonical Variate (Tiller Maturity)

$$
\text { ○ Jun. } \square \text { Jul. } \nabla \text { Aug. } \nabla \text { Oct. }
$$

Fig. 1. Plots of the first canonical variate of chemical (forage quality) and physical characteristics (tiller maturity) for (a) sand bluestem, (b) prairie sandreed, and (c) little bluestem; ${ }^{\star \star}$ indicates signiffcance at $P<0.01$. species attained higher stages of development in 1991, with observations higher on the maturity axis, particularly in the later parts of the growing season. Variation in forage quality was also noted, and mostly related to the progressive increase in variability during the growing season (Fig. la-c). Part of the variation noted during July through October can be attributed to the clonal, indeterminate growth form of all 3 species; diverse populations of tillers were present, containing many phenological stages of development. Greater numbers of older plants of higher structural complexity, and lower overall forage quality, were present. Similar responses have been noted in univariate studies. Cell wall content increased and IVDMD and protein content declined with increases in phenology in temperate grasses and legumes (Sanderson and Wedin 1989). Similar responses have been noted in other studies on the effects of advancing growth stage and growing season on forage quality of important Sandhills grasses (Burzlaff 1971, Hendrickson 1992). Forage quality within plant canopies also varies with development. Herbage in the upper portions of the warm-season grass Hemarthia altissima (Poir.) Stapf. et C.E. Hubb. had greater leaf bulk density, IVDMD (5-10\%), and protein content (25-100\%) as compared to foliage in the lower parts of the canopy (Holderbaum et al. 1992). Such spatial distributions in forage quality within plants is an important factor in the decline of forage palatability with plant maturation (Coleman 1992).

\section{Conclusions}

Results of this study support the existence of a general relationship between composite indices of forage quality and tiller maturation, which incorporated groups of related variables. Robust relationships were noted among suites of physical and chemical characteristics. Most of the relationships were driven by changes occurring in tillers as growing degree days accumulated with the

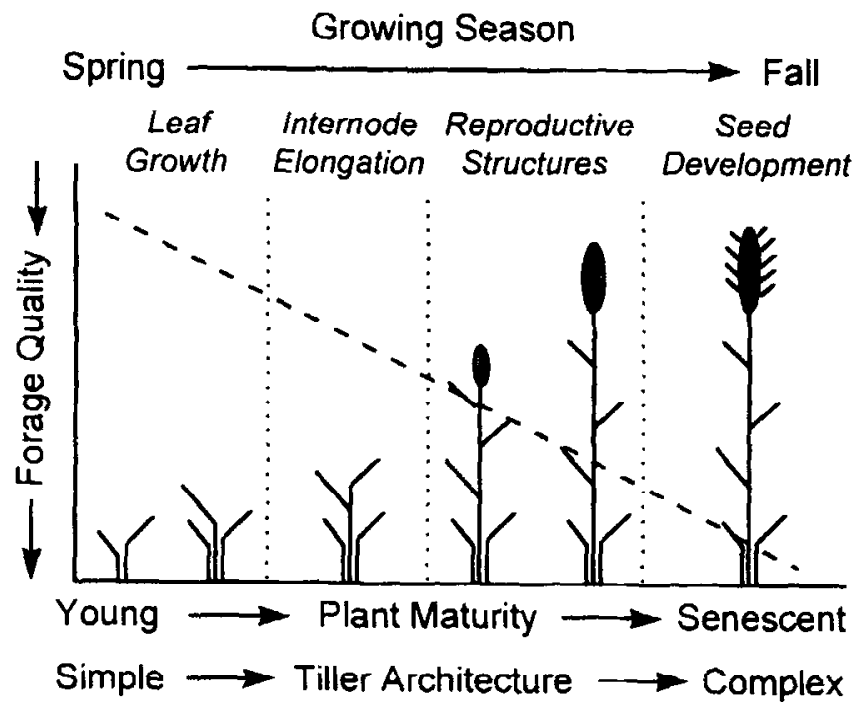

Fig. 2. Diagrammatic illustration of the relationship between tiller maturation, structural complexity, and forage quality in 3 warm-season grasses; the diagonal line represents change in forage quality. 
advance of growing season (Fig. 2). Generally, as growing degree days increased, tillers attained more advanced growth stages and were taller and heavier. Plants also became more structurally complex, with a wider array of parts (leaves, nodes, internodes, flowering structures) within their canopies, and number of components per plant part. A corresponding increase in anti-quality compounds in cell walls also occurred, accompanied by a decline in palatability factors (Fig. 2). The relationships among characteristics describing forage quality underscore the importance of considering how suites of related variables interact when describing the palatability and value of herbage to grazers. Such findings also underscore the importance of selective grazing to large herbivores. Native forage species represent a dynamic food base from which ungulates must consume a diet, and present a resource of spatially and temporally variable quality to grazers (Stuth 1991).

Results of this analysis can be applied to practical management problems. The linear combination of physical characteristic coefficients can be used to generate a "maturity-structure" score that is correlated to a given "quality" index. This forage quality score could then be found within a table containing ranges of crude protein, digestibilities, and cell wall fractions for given scores. If a random sample of tillers (with adequate sample size) were measured, an estimate of the quality of available forage for the 3 dominant warm-season grasses of Sandhills rangeland could be ascertained on similar sites.

One area of future interest for studies utilizing multi-dimensional analyses would be the inclusion of numbers of growth stages and new vegetative tillers produced during the growing season to the physical characteristics. An alternative approach to this study would be the combination of climatic factors, chemical and phyiscal variables of tillers into a dataset to examine relationships between composite indices of growing conditions, forage quality, and tiller development.

\section{Literature Cited}

Albersheim, P. 1975. The walls of growing plant cells. Sci. Amer. 232:80-95.

Akin, D.E. 1989. Histological and physical factors affecting digestibility of forages. Agron. J. 81:17-25.

Arnon, D.I. 1949. Copper enzymes in isolated chloroplasts. Polyphenol oxidase in Beta vulgaris. Plant Phys. 24:1-15.

Association of Official Agricultural Chemists. 1965. Official methods of analysis of the Assoc. of Official Agr. Chem., 10th edition., Washington, DC.

Bidwell, T.G. and D.M. Engle. 1992. Relationships of fire behavior to tallgrass prairie herbage production. J. Range Manage. 45:579-584.

Brejda, J.J., L.E. Moser, and S.S. Waller. 1989. Rhizome and tiller development of three Nebraska Sandhills warm-season grasses. p. 211 215. In: T.B. Bragg and J. Stubbendieck (eds.). Proc. 11th. North Amer. Prairic Conf. Lincoln, Nebr.

Burzlaff, D.F. 1962. A soil and vegetation inventory and analysis of three Nebraska Sandhills range sites. Univ. of Nebr. Agr. Exp. Sta. Res. Bull. 206.

Burzlaff, D.F. 1971. Seasonal variations of the in-vitro dry-matter digestibility of three Sandhill grasses. J. Range Manage. 24:60-63.

Bremner, J.N. 1965. Total nitrogen. p. 1149-1178. In: C.A. Black et al. (eds.). Methods of soil analysis, Part. 2. Chemical and Microbiological Properties. Amer Soc. Agron., Soil Sci. Soc. Amer., Madison, Wisc.

Coleman, S.W. 1992. Plant-animal interface. J. Prod. Agr. 5:7-13.

Dahl, B.E. and D.N. Hyder. 1977. Developmental morphology and management implications. pp. $257-290$. In: R.E. Sosebee (ed.).
Rangeland plant physiology. Kange Science Series, No. 4. Soc. for Range Manage., Denver, Colo.

Goering, H.K. and P.J. Van Soest. 1970. Forage fiber analysis (apparatus, reagents, procedures, and some applications). USDA Agr. Handb. 379.

Great Plains Flora Association. 1986. Atlas of the flora of the Great Plains. T.M. Barkley (ed.). Iowa State Univ. Press, Ames, Iowa.

Hendrickson, J.R. 1992. Developmental morphology of two Nebraska sandhills grasses and its relationship to forage quality. M.S. Thesis, Univ. of Nebraska. Lincoln, Nebr.

Hiscox, J.D. and G.F. Israelstam. 1979. A method for the extraction of chlorophyll from leaf tissue without maceration. Can. J. Bot. 57:1332-1334.

Hoehne, O.E. 1966. Cattle preference as related to chemical components of native range plants. Ph.D. Diss., Univ. of Nebraska, Lincoln, Nebr.

Holderbaum, J.F., L.E. Sollenberger, K.H. Quesenberry, J.E. Moore, and C.S. Jones, Jr. 1992. Canopy structure and nutritive value of limpograss pastures during mid-summer to early autumn. Agron. J. 84:11-16.

Johnson, R.A. and D.W. Wichern. 1988. Applied multivariate statistical analysis. Second edition. Prentice-Hall Inc. Englewood Cliffs, N.J.

Jung, H.G., G.L. Bennet, and T. Sahlu. 1989. Magnitude of diet selection by sheep grazing smooth bromegrass. J. Anim. Sci. 67:2106-2115.

Ludwig, J.A. and J.F. Reynolds. 1988. Statistical ecology: a primer on methods and computing. John Wiley \& Sons, New York, N.Y.

Marten, G.L. and R.F. Barnes. 1979. Prediction of energy digestibility of forages with in vitro rumen fermentation and fungal enzyme systems. p. 61-71. In: W.D. Pigden et al. (eds.). Standardization of analytical methodology of feeds. Intl. Dev. Res. Centert, Ottawa, Canada.

Moore, K.J., L.E. Moser, K.P. Vogel, S.S. Waller, B.E. Johnson, and J.F. Pederson. 1991. Describing and quantifying growth stages of perennial forage grasses. Agron. J. 83:1073-1077.

Murphy, J.S. and D. D. Briske. 1992. Regulation of tillering by apical dominance: chronology, interpretive value, and current perspectives. J. Range Manage. 45:419-429.

National Oceanic and Atmospheric Administration. 1991. Climatological data (Nebraska). Asheville, N.C.

NCSS. 1990. Number Cruncher Statistical System, Version 5.03. Kaysville, Ut.

Northup, B.K. 1993. Utilization of native forages of the Nebraska Sandhills by yearling cattle. Ph.D. Diss. Univ. of Nebraska. Lincoln, Nebr.

Northup, B.K., J.E. Brummer, and J.T. Nichols. 1994. Plant species recorded on the Gudmundsen Sandhills Laboratory grazing study: 1989-91. p. 37-39. In: Univ. of Nebr. GSL Res. Rep. WCC94-01.

Porra, R.J., W.A. Thompson, and P.E. Kriedemann. 1989. Determination of accurate extinction coefficients and simultaneous equations for assaying chlorophylls $a$ and $b$ extracted with four different solvents: verification of the concentration of chlorophyll standards by atomic absorption spectroscopy. Biochim. Biophys. Acta 975:384-394.

Sanderson, M.A. and W.F. Wedin. 1989. Phenological stage and herbage quality relationships in temperate grasses and legumes. Agron. J. 81:864-869

SAS. 1986. SAS/STAT user's guide. Release 6.03. SAS Instit., Cary, N.C.

Smith, D.S., G.M. Paulsen, and C.A. Raguse. 1964. Extraction of total available carbohydrates from grass and legume tissues. Plant Phys. 9: $960-962$,

Stuth, J.W. 1991. Foraging behavior. p. 65-83. In: R.K. Heitschmidt and J.W. Stuth (eds.). Grazing management: an ecological perspective. Timber Press, Inc., Portland, Ore.

Tieszen, L.L. 1970. Photosynthetic properties of some grasses in eastern South Dakota. Proc. S.D. Acad. Sci. 49:78-89.

Van Soest, P.J. 1982. Nutritional ecology of the ruminant: ruminant metabolism, nutritional strategies, the cellulolytic fermentation and the chemistry of forages and plant fibers. O \& B Books, Corvallis, Ore.

Weaver, J.E. 1965. Native vegetation of Nebraska. Univ. of Nebraska Press, Lincoln, Nebr. 